\title{
PENERAPAN KEPEMIMPINAN KEPALA SEKOLAH DALAM MENINGKATKAN KINERJA GURU PADA JENJANG SEKOLAH MENENGAH PERTAMA (SMP)
}

\author{
HERAWATI SYAMSUL \\ Program Pascasarjana Pendidikan Agama Islam, UMI Makassar \\ Jl. Urip Sumoharjo No. 225 Makassar \\ Email: heraadipatta@gmail.com
}

\begin{abstract}
:
the success of an organization or institution is influenced by various factors, both factors coming from within and coming from the environment. Of these various factors, motivation is a factor that is dominant and can move other factors toward the effectiveness of work. In some instances, motivation is often equated with a car's engine and steering wheel, which serves as a driving force and driver. The biggest source of motivation comes from the leader in this case is the principal. Principal leadership is an interrelated chain of aspects of teacher performance, pupils and all elements of the educational organization, so it is necessary to continuously improve in the form of self-development, insight so as to affect the progress of the school he leads.
\end{abstract}

Keywords: leadership, performance, quality, school, teaching.

\section{PENDAHULUAN}

epemimpinan kepala sekolah yang baik harus dapat mengupayakan peningkatan kinerja guru melalui program pembinaan kemampuan tenaga kependidikan. Seorang pemimpin untuk dapat memulai memimpin dengan baik adalah dengan memiliki sifat kasih sayang atau mencintai terhadap apa yang dipimpinnya. Dengan dimilikinya sifat ini, maka pemimpin akan menjadikan sumber daya manusia sebagai aset utama yang paling penting dan tidak tertandingi oleh aset apa pun.

Di dalam organisasi, lembaga, maupun di lembaga pendidikan, "pimpinan" merupakan motor penggerak dan penentu arah kebijakan organisasi. Dalam sekolah/madrasah, pemimpin akan menentukan bagaimana tujuan-tujuan pendidikan dapat direalisasikan sehingga kepala sekolah dituntut senantiasa meningkatkan efektivitas kinerja dan memuaskan hasil kinerja lembaga.

Faktor lain yang mempengaruhi pendidikan adalah kinerja guru yang berkualitas. Seorang guru dituntut untuk bisa memberikan kontribusi yang besar terhadap pendidikan di lingkungan sekolah terutama dalam hal pembelajaran, karena keberhasilan siswa sangat ditentukan oleh kinerja guru yang professional dalam menjalankan tugas, fungsi dan peranannya sebagai pendidik.

Kepala sekolah tidak hanya meningkatkan tanggung jawab dan otoritasnya dalam program-program sekolah, kurikulum dan keputusan personil, tetapi Juga 
memiliki tanggung jawab untuk meningkatkan akuntabilitas Keberhasilan siswa dan programnya. Kepala sekolah harus pandai dalam memimpin kelompok dan pendelegasian tugas dan wewenang.

Berbagai upaya penting dan strategis yang diagendakan untuk mengoptimalkan kinerja kepala sekolah ini sangat tergantung pada kemauan dan tekad kepala sekolah untuk menjadikan dirinya sebagai pimpinan yang sukses dengan kinerja optimal. Seorang pimpinan yang bukan sekedar berhasil mencapai puncak-puncak kepemimpinan, tetapi juga dapat mengantar warga sekolah dan terutama peserta didik berhasil meraih prestasi melebihi dirinya. Guru merupakan faktor utama dalam proses pendidikan. Guru memiliki peranan yang sangat penting dalam menentukan keberhasilan pendidikan. Di kelas gurulah yang menjadi subjek utama dalam kegiatan pembelajaran.

Guru merupakan salah satu komponen yang sangat menentukan untuk terselenggaranya proses pendidikan, keberadaan guru merupakan pelaku utama sebagai fasilitator penyelenggara proses belajar siswa. Oleh karena itu kinerja guru berhubungan dengan program pendidikan nasional. Guru sebagai faktor menentukan mutu pembelajaran. Karena guru berhadapan langsung dengan para peserta didik dalam proses pembelajaran di kelas. Di tangan guru mutu kepribadian mereka dibentuk. Karena itu, perlu sosok guru kompeten, tanggung jawab, terampil, dan berdedikasi tinggi. Guru adalah kurikulum berjalan. Sebaik apa kurikulum dan sistem pendidikan yang ada, tanpa didukung kemampuan guru, semuanya akan sia-sia. Guru kompeten efektif, dan bertanggungjawab mengawal perkembangan peserta didik sampai suatu titik maksimal. Tujuan akhir seluruh proses pendampingan guru adalah tumbuhnya pribadi dewasa yang utuh.

\section{PEMBAHASAN}

\section{Teori Kepemimpinan Kepala Sekolah}

Kepemimpinan kepala sekolah merupakan suatu kemampuan dan kesiapan kepala sekolah untuk mempengaruhi, membimbing, mengarahkan, dan menggerakkan staf sekolah agar dapat bekerja secara efektif dalam rangka mencapai tujuan pendidikan dan pengajaran yang telah ditetapkan, atau bisa dikatakan bantuan yang diberikan oleh kepala sekolah terhadap penetapan pencapaian tujuan pendidikan.

Di dalam lingkungan organisasi, kepemimpinan terjadi melalui dua bentuk, yaitu: kepemimpinan formal dan kepemimpinan informal. Kepemimpinan formal terjadi apabila di lingkungan organisasi jabatan otoritas formal dalam organisasi tersebut diisi oleh orang-orang yang muncul dan berpengaruh terhadap orang lain karena kecakapan khusus atau berbagai sumber yang dimilikinya dirasakan mampu memecahkan persoalan organisasi serta memenuhi kebutuhan dari anggota organisasi yang bersangkutan. 


\section{Indikator Kepemimpinan Kepala Sekolah Efektif}

Kepala sekolah yang efektif sedikitnya harus mengetahui, menyadari dan memahami tiga hal: (1) mengapa pendidikan yang berkualitas diperlukan di sekolah; (2) apa yang harus dilakukan untuk meningkatkan mutu dan produktivitas sekolah; dan (3) bagaimana mengelola sekolah secara efektif untuk mencapai prestasi yang tinggi.

Indikator-indikator kepemimpinan kepala sekolah yang efektif sebagai berikut:

(1) Menekankan kepada guru dan seluruh warga sekolah untuk memenuhi normanorma pembelajaran dengan disiplin yang tinggi.

(2) Membimbing dan mengarahkan guru dalam memecahkan masalah-masalah kerjanya, dan bersedia memberikan bantuan secara proporsional dan profesional.

(3) Memberikan dukungan kepada para guru untuk menegakkan disiplin peserta didik.

(4) Menunjukkan sikap dan prilaku teladan yang dapat menjadi panutan atau model bagi guru, peserta didik, dan seluruh warga sekolah.

(5) Membangun kelompok kerja aktif, kreatif, dan produktif.

(6) Memberikan ruang pemberdayaan sekolah kepada seluruh warga sekolah.

Demikianlah enam indikator kepemimpinan kepala sekolah yang mana apabila terlaksana dengan baik maka organisasi di sekolah dapat mencapai tujuan yang ditetapkan.

\section{Kompetensi Kepala Sekolah}

Kompetensi yang harus dimiliki oleh Kepala Sekolah / Madrasah berdasarkan Peraturan Menteri Pendidikan Nasional Nomor 13 Tahun 2007 tentang Standar Kepala Sekolah/Madrasah terdiri dari 5 kompetensi di antaranya: kompetensi manajerial, kompetensi kewirausahaan, kompetensi supervisi, kompetensi kepribadian, dan kompetensi sosial.

Berikut unsur-unsur selengkapnya tentang 5 kompetensi yang harus dimiliki oleh kepala sekolah ataupun kepala madrasah:

(1) Kompetensi Manajerial

(2) Kompetensi Kewirausahaan

(3) Kompetensi Supervisi

(4) Kompetensi Kepribadian

(5) Kompetensi Sosial

\section{Kinerja Guru}

Setiap individu yang diberi tugas atau kepercayaan untuk bekerja pada suatu organisai tertentu diharapkan mampu menunjukkan kinerja yang memuaskan dan memberikan konstribusi yang maksimal terhadap pencapaian tujuan oraganisasi tersebut. 
Dalam Kamus Besar Bahasa Indonesia, kinerja diartikan sebagai sesuatu yang dicapai atau prestasi yang diperlihatkan. Kinerja adalah sebuah kata dari bahasa Indonesia dari kata dasar "kerja" yang menerjemahkan kata dari bahasa asing prestasi. Bisa pula berarti hasil kerja.

Undang-undang Republik Indonesia Nomor 14 Tahun 2005 Tentang Guru dan Dosen Pasal 35 ayat (1) beban kerja guru mencakup kegiatan pokok yaitu merencanakan pembelajaran, melaksanakan pembelajaran, membimbing dan melatih peserta didik, serta melaksanakan serta melaksanakan tugas tambahan.

Dalam hal ini evaluasi kinerja (Performance Appraisal) sangat diperlukan sebagai feedback dari serangkaian kegiatan dalam organisasi. Evaluasi kinerja sangat diperlukan karena di dalam kegiatan evaluasi kinerja setiap karyawan di dalam organisasi akan dinilai dan dievaluasi prestasi kerjanya.

Banyak faktor yang dapat mempengaruhi kinerja seorang guru. Maka sebagai pimpinan tertinggi di sekolah, seorang kepala sekolah harus mampu memberikan energi positif yang mampu menggerakkan para guru untuk melaksanakan tugasnya secara sungguh-sungguh dan penuh tanggung jawab sehingga kinerja mereka menjadi lebih baik dan lebih baik lagi. Sebagai pemimpin yang mempunyai pengaruh, seorang kepala sekolah harus terus berusaha agar ide, nasehat, saran dan (jika perlu) instruksi dan perintah dan kebijakannya di ikuti oleh para guru binaannya. Dengan demikian ia dapat mengadakan perubahan-perubahan dalam cara berfikir, dalam bersikap dan dalam bertindak atau berperilaku. Maka menjadi tuntutan bagi seorang kepala sekolah harus selalu merefresh pengetahuan dan wawasan keilmuannya agar nantinya dapat mendukung tugasnya sebagai seorang pemimpin.

Dalam mendukung kinerja guru perlu dukungan kompetensi guru yang profesional. Kompetensi guru diukur dengan 10 kompetensi guru dilihat dari aspekaspek yaitu (a) menguasai bahan ajar; (b) mengelola program belajar mengajar; (c) mengelola kelas; (d) menggunakan media/sumber; (e) menguasai landasasanlandasan kependidikan; (f) mengelola interaksi belajar-mengajar; (g) menilai prestasi siswa untuk pendidikan dan pengajaran; (h) mengenal fungsi dan program layanan binbingan serta penyuluhan; (i) mengenal dan menyeleng- garakan administrasi sekolah; (j) memahami prinsip-prinsip dan menafsirkan hasil-hasil penelitian pendidikan guna keperluan pengajaran.

Adapun instrument penilaian kinerja guru menurut sistem pendidikan Nasional ada enam yaitu:

(1) Perencanaan pembelajaran

(2) Pelaksanaan pembelajaran

(3) Penilaian hasil pembelajaran

(4) Melatih dan membimbing

(5) Tugas tambahan

(6) Mengembangkan kegiatan profesi 
Upaya peningkatan mutu pembelajaran antara lain melalui revitalisasi kinerja kepala sekolah yaitu kegiatan yang harus dilakukan kepala sekolah dan kepemimpinan kepala sekolah yang profesional. Dengan upaya ini diharapkan adanya peningkatan mutu pendidikan nasional. Peningkatan mutu pembelajaran atau mutu sekolah tertuju pada mutu Iulusan. Merupakan suatu yang mustahil, pendidikan atau sekolah menghasilkan Iulusan yang bermutu, jika tidak melalui proses pembelajaran yang bermutu pula. Dan hal yang mustahil pula, terjadi proses pembelajaran yang bermutu jika tidak didukung oleh faktor-faktor penunjang proses pembelajaran yang bermutu pula. Proses pembelajaran yang bermutu harus didukung oleh personalia, seperti administrator, guru, konselor, dan tata usaha yang bermutu dan profesional.

\section{Indikator-indikator Kinerja Guru}

Kinerja seseorang dapat ditingkatkan apabila ada kesesuaian antara pekerjaan dengan keahliannya, begitu pula halnya dengan penempatan guru pada bidang tugasnya. Menempatkan guru sesuai dengan keahliannya secara mutlak harus dilakukukan. Apabila guru diberikan tugas yang tidak sesuai dengan keahliannya akan berakibat menurunnya cara kerja dan hasil pekerjaan mereka, juga akan menimbulkan rasa tidak puas pada diri mereka. Rasa kecewa akan menghambat perkembangan moral kerja guru.

Selain dipengaruhi oleh keahlian dan kemampuan dari seorang guru, kinerja dipengaruhi juga oleh kepuasan kerja yaitu perasaan individu terhadap pekerjaan yang memberikan kepuasan bathin sehingga pekerjaan tersebut disenangi dan dilaksanakan dengan baik. Untuk mengetahui keberhasilan kinerja perlu dilakukan evaluasi dengan berpedoman pada parameter dan indikator yang telah ditetapkan.

Kinerja guru sangat penting untuk dievaluasi karena guru mengemban tugas professional artinya tugas-tugas hanya dapat dikerjakan dengan kompetensi khusus yang diperoleh melalui program pendidikan. Guru memiliki peranan yang sangat besar bagi terlaksananya kegiatan belajar mengajar yang dapat diklasifikasikan guru sebagai:

(1) Demonstrator

(2) Pengelola kelas

(3) Mediator dan Fasilitator

(4) Evaluator

Jadi peran guru dalam proses belajar mengajar yaitu sebagai demonstrator sehingga guru itu mampu meragakan apa yang di ajarkannya. Hendaknya mampu mengelola kelas sebagai lingkungan belajar, lingkunga sekolah yang perlu diorganisasi, diatur dan diawasi agar kegiatan belajar mengajar terarah kepada tujuan pendidikan. Selain itu guru pun menjadi mediator atau perantara dalam kaitan antar manusia, maka guru harus terampil mempergunakan pengetahuan tentang bagaimana berinteraksi dan berkomunikasi. Demikian pula dalam satu kali 
proses belajar mengajar guru hendaknya menjadi evaluator yang baik, maksudnya untuk mengetahui apakah tujuan yang telah dirumuskan itu tercapai atau belum, dan apakah materi yang di ajarkan sudah cukup tepat, semua pertanyaan tersebut akan dapat di jawab melalui kegiatan evaluasi atau penilaian.

\section{Hubungan Kepemimpinan Kepala Sekolah Kinerja Guru}

Keberhasilan seorang pemimpin akan terwujud apabila pemimpin tersebut memperlakukan orang lain atau bawahannya dengan baik, serta memberikan motivasi agar mereka menunjukan performance yang tinggi dalam melaksanakan tugas. Menurut Hadari Nawawi (1983:81) kepemimpinan adalah kemampuan menggerakan, memberikan motivasi dan mempengaruhi orang-orang agar bersedia melakukan tindakan-tindakan yang terarah pada pencapaian tujuan melalui keberanian mengambil keputusan tentang kegiatan yang harus dilakukan. Dari uraian diatas dapat disimpulkan bahwa kepemimpinan kepada sekolah sebagai Seorang Supervisor dalam pengawasan Kinerja Guru akan berahasil jika kepala sekolah memperhatikan hasil yang dicapai serta memperlakukan guru dengan baik, sehingga mereka mampu menunjukan performace yang lebih baik.

Kinerja guru merupakan aktivitas yang dilakukan guru sesuai dengan profesi yang diembannya, untuk dapat melakukan tindakan yang sesuai dengan profesi yang diembannya sangat terkait dengan ada tidaknya kepuasan dalam bekerja. Kepuasan bekerja berhubungan erat dengan motivasi kerja. Menurut Hamid Darmadi (1994:107) kepuasan kerja timbul dengan baik jika seseorang memiliki motivasi kerja yang baik pula.

Asmara (dalam Hamid Darmadi; 1994:118) menjelaskan bahwa tindakan kepemimpinan kepala sekolah terhadap kematangan kerja guru dan kepuasan kerja guru berkorelasi positif, maksudnya kematangan kerja yang tinggi cenderung diikuti oleh kepuasan kerja yang tinggi pula

Robin (1986:263) berpendapat bahwa keberhasilan dan kegagalan organisasi banyak ditentukan oleh keberhasilan dan kegagalan pemimpin dalam memainkan perannya. Peranan pemimpin dalam menggerakkan anggota memiliki peranan yang strategik. Secara umum dapat dikatakan bahwa seorang pemimpin pada tingkat apapun hendaknya memiliki wawasan yang luas dan menjangkau ke masa depan, mampu membuat keseimbangan, keserasian, dan keserasian dalam membuat keputusan untuk menggerakkan anggotanya dalam mewujudkan sasaran dan mencapai tujuan organisasi. Pemimpin harus berperan sebagai individu teladan (to do the right things), sebagai komandan, sebagai guru yang bertugas menyiapkan kader, sebagai seorang bapak yang bijak, seorang sahabat yang penuh pengertian dan berjiwa karsa.

Dalam kehidupan berorganisasi, pemimpin memegang peranan yang sangat penting, bahkan sangat menentukan dalam usaha mencapai tujuan organisasi. Seorang pemimpin dalam melakukan aktivitasnya memerlukan sekelompok orang 
lain yang disebut bawahan. Selain bawahan, pemimpin juga membutuhkan sarana dan prasarana dalam rangka memperlancar tugasnya sebagai pemimpin. Pemimpin Juga dituntut untuk membina hubungan baik dan menyenangkan dengan bawahan dalam usaha mencapai tujuan organisasi.

Seorang pemimpin yang berhasil adalah seorang pemimpin yang memiliki kemampuan pribadi tertentu, mampu membaca keadaan bawahannya dan lingkungannya. Faktor yang harus diketahui dari bawahannya adalah kematangan mereka, sebab ada kaitannya dengan gaya kepemimpinan. Hal ini dimaksudkan agar pemimpin dapat bekerja dengan tepat menerapkan pengaruhnya pada bawahan sehingga pemimpin memperoleh ketaatan memadai.

Keberadaan pemimpin yang efektif dan dinamis dalam struktur organisasi sangat strategis. Karena dengan adanya komitmen yang tinggi seorang pemimpin untuk meningkatkan kualitas para bawahannya, maka diharapkan akan meningkat pula kualitas bawahannya. Pemimpin yang efektif dan dinamis akan mampu mengendalikan, mengarahkan dan memotivasi bawahannya ke arah tercapainya produktivitas kerja pegawai, seperti yang diharapkan oleh pemimpin dalam suatu organisasi.

Agar organisasi dapat berjalan dengan baik, salah satunya unsur yang berperan adalah kepemimpinan. Kepemimpinan sebagai proses mempengaruhi interprestasi para pengikut terhadap suatu peristiwa, memilih tujuan kelompok atau organisasi, pengorganisian dan aktivitas-aktivitas kerja, memotivasi para pengikut untuk mencapai sasaran, pemeliharaan hubungan kerja sama dan kerja kelompok, serta perolehan dukungan dan kerja sama dari orang-orang yang berada di luar kelompok atau organisasi. Definisi ini memberikan pengertian yang sangat jelas, bahwa pihak atasan (pemimpin) yang mempengaruhi kegiatan para pengikut melalui proses komunikasi ke arah tindakan mencapai tujuan. Kepemimpinan adalah pengaruh dan tindakan tingkah laku kepercayaan dan perasaan dari seseorang dalam sebuah sistem sosial dengan orang lain, dengan harapan adanya kerja sama dari orang yang sedang dipengaruhi. Kepemimpinan merupakan tingkah laku seorang individu untuk mengarahkan aktivitas-aktivitas kelompok ke arah pencapaian tujuan organisasi. Pendapat tersebut menunjukkan bahwa kepemimpinan mengacu kepada tingkah laku seorang pemimpin dalam memberikan bimbingan, arahan kepada para bawahannya dalam rangka mencapai tujuan organisasi. Jadi, keberhasilan seorang pemimpin ditentukan oleh perilaku dari pemimpin tersebut.

Kepemimpinan manajerial sebagai proses mengarahkan dan mempengaruhi aktivitas yang berkaitan dengan tugas dari para anggota kelompok. Ada tiga implikasi penting dari batasan tersebut:

Kepemimpinan harus melibatkan orang lain, bawahan atau pengikut. Karena kesediaan mereka menerima pengarahan dari pimpinan, anggota kelompok membantu menegaskan status pemimpin dan memungkinkan proses 
kepemimpinan. Tanpa bawahan, semua sifat-sifat kepemimpinan seorang manajer akan menjadi tidak relevan.

Kepemimpinan mencakup distribusi kekuasaan yang tidak sama diantara pemimpin dan anggota kelompok, yang tidak dapat dengan cara yang sama mengarahkan aktivitas pemimpin. Meskipun demikian anggota kelompok jelas akan mempengaruhi aktivitas tersebut dengan sejumlah cara.

Di samping secara sah mampu memberikan bawahan atau pengikutnya. Perintah atau pengarahan, pemimpin juga dapat mempengaruhi bawahan dengan berbagai cara lain. Shermerhorn, Hunt dan Obson menyatakan kepemimpinan adalah suatu proses penggunaan kekuatan untuk memperoleh pengaruh manusia.

Mengacu kepada pendapat tersebut bahwa kepemimpinan dinyatakan sebagai proses, artinya kepemimpinan itu berlangsung dalam kurun waktu cukup lama yang dimulai dari membuat perencanaan (Planning) pengorganisasian (Organizing), pembimbingan (Directing), Pengawasan (Controlling) dan kembali lagi kepada pembuatan perencanaan untuk kegiatan selanjutnya. Kepemimpinan merupakan proses mempengaruhi aktivitas seseorang atau kelompok orang untuk mencapai suatu tujuan dalam situasi tertentu. (Blanchard, 1995:99)

Definisi di atas menunjukkan bahwa situasi apapun jika seseorang berusaha mempengaruhi perilaku orang lain atau kelompok, maka pada saat itu sedang berlangsung proses kepemimpinan. Setiap saat seorang berusaha mempengaruhi perilaku orang lain, maka orang itu adalah pemimpin potensial dan orang yang dipengaruhi adalah pengikut potensial. Oleh karena itu posisi seseorang tidak menjadi penghalang orang itu adalah atasan, rekan sejawat, bawahan, kawan atau sanak keluarga. Menurut teori seorang pemimpin tidak harus menjadi manajer dalam suatu organisasi atau perusahaan tertentu.

Kepemimpinan merupakan kecakapan untuk meyakinkan orang-orang agar mengusahakan secara tegas tujuan-tujuannya dengan penuh semangat. Hicks, and Gullet. (1996: 492) Dalam pernyataan tersebut nampak adanya faktor manusia yang mengikat suatu kelompok secara bersama-sama dan mendorongnya ke arah tujuan.

Dalam pengertian yang paling mendasar, kepemimpinan berarti berada di barisan paling depan, menggunakan badan, gerakan mau dan keterampilan komunikasi anda untuk memberi arahan kepada orang lain, jalan mana yang harus ditempuh. Selanjutnya dijelaskan bahwa kepemimpinan yang berhasil menurut Hicks, and Gullet. (1996: 492)

Kepemimpinan sebagaimana dikatakan oleh Hadari Nawawi juga diartikan kemampuan menggerakkan, memberikan motivasi dan mempengaruhi orang-orang agar tersedia melakukan tindakan-tindakan yang terarah pada pencapaian tujuan melalui keberanian mengambil keputusan tentang kegiatan yang harus dilakukan. Pendapat tersebut menunjukkan bahwa kepemimpinan mengacu pada perilaku seorang pemimpin. la memberi pengarahan, bimbingan, tuntunan kepada para 
bawahan dalam rangka mencapai tujuan organisasi. Dalam hal ini, keberhasilan seorang pemimpin ditentukan oleh perilaku si pemimpin tersebut.

Merujuk kepada teori-teori tersebut, maka secara sederhana dapat disimpulkan bahwa pemimpin adalah kemampuan yang dimiliki oleh seseorang (pemimpin) untuk mempengaruhi orang lain (bawahan) dalam rangka untuk mencapai tujuan organisasi.

Keberhasilan Suatu organisasi atau lembaga dipengaruhi oleh berbagai faktor, baik faktor yang datang dari dalam maupun yang datang dari lingkungan. Dari berbagai faktor tersebut, motivasi merupakan suatu faktor yang cukup dominan dan dapat menggerakkan faktor-faktor lain ke arah efektivitas kerja. Dalam hal tertentu motivasi sering disamakan dengan mesin dan kemudi mobil, yang berfungsi sebagai penggerak dan pengarah.

Setiap bawahan memiliki karakteristik khusus, yang satu sama lain berbeda. Hal tersebut memerlukan perhatian dan pelayanan khusus pula dari pemimpinnya, agar mereka dapat memanfaatkan waktu untuk meningkatkan kinerjanya. Perbedaan pegawai tidak hanya dalam bentuk fisik, tetapi juga dalam psikisnya, perlu diupayakan untuk membangkitkan motivasi bawahan dan faktor-faktor lain yang mempengaruhinya.

Menurut H. Jodeph Reitz (1981) faktor-faktor yang mempengaruhi efektivitas pemimpin meliputi: 1) Kepribadian (personality) pengalaman masa lalu dan harapan pemimpin, 2) harapan dan perilaku atasan, 3) karakteristik harapan dan perilaku bawahan, dan 4) Harapan dan perilaku rekan.

Usaha menciptakan disiplin kerja dapat dilakukan melalui perhatian dan kerja sama dari pemimpin, yaitu perilaku kepemimpinan yang menciptakan hubungan kerja dengan karyawan yang didasari rasa saling menghormati dan menghargai. Sondang P. Siagian (1979:26) menyatakan, "Setiap orang dalam organisasi bagaimana pun rendahnya pendidikan dan kedudukannya ingin dihargai oleh atasan, rekan setingkat dan organisasi lainnya.

Pendapat tersebut di atas didukung oleh James J. Cribbin (1990:136) yang menyatakan bahwa jika para pemimpin bersikap egoistis, tidak mau bersikap kooperatif, tidak mau berkorban, cuma ingin mencari untung melulu maka organisasi akan menjadi kacau berantakan dan tujuan tidak akan tercapai. Pemimpin demikian akan banyak menebarkan ketakutan, keresahan, kecemasan, kesedihan, kesengsaraan di tengah anak buahnya.

Dari kedua pendapat di atas jelas bahwa pemimpin hendaknya memperlakukan bawahan sebaik-baiknya sebagai rekan kerja, dalam hal pekerjaan maupun secara moral seperti kejujuran, kesederhanaan, tidak egois akan tetapi segala tindakannya untuk kepentingan anggota. Dengan menciptakan suasana yang sehat dan menyenangkan akan membentuk moral yang tinggi. Dengan moral staff yang tinggi akan dapat dikembangkan potensi-potensi sehingga disiplin diri akan tumbuh serta karyawan akan memberikan segala kemampuannya untuk 
bekerja seoptimal mungkin. Untuk menjaga konsistensi disiplin kerja perlu adanya keteladanan yakni pimpinan harus dijadikan panutan atau contoh. "Untuk lebih mengefektifkan peraturan yang dikeluarkan dalam menegakkan kedisiplinan perlu adanya teladan pimpinan."

Pendapat ini didukung oleh Paul Hersey yang menyatakan bahwa jalan baik untuk mendisiplinkan bawahan atau rakyat banyak ialah pemimpin-pemimpin harus memberikan kecintaan, pengorbanan dan teladan, kejujuran dan kesederhanaan sesuai ucapan dan tingkah lakunya, mau bekerja keras untuk kesejahteraan anggota dan bukan untuk kemakmuran dirinya sendiri.

Senada dengan pendapat di atas Bill Greech (1996:346) dalam terjemahan Alexander Sudiro mengatakan, "Pimpinlah dengan memberi contoh-contoh yang positif bukan menetapkan peraturan lewat teror, ancaman, omong besar dan intimidasi." Dengan keteladanan dari pihak pimpinan, disiplin karyawan dapat dibina sehingga kedisiplinan yang muncul tidak sekedar karena takut akan tetapi muncul dari kesadaran.

Adapun fungsi kepemimpinan pendidikan menurut Soekarto Indrafachrudi (1993:33) adalah pada dasarnya dapat dibagai menjadi dua yaitu:

a) Fungsi yang bertalian dengan tujuan yang hendak dicapai

- Pemimpin berfungsi memikirkan dan merumuskan dengan teliti tujuan kelompok serta menjelaskan supaya anggota dapat berkerjasama mencapai tujuan itu.

- Pemimpin berfungsi memberi dorongan kepada anggota-anggota kelompok untuk menganalisis situasi supaya dapat dirumuskan rencana kegiatan kepemimpinan yang dapat memberi harapan baik.

- Pemimpin berfungsi membantu anggota kelompok dalam memberikan keterangan yang perlu supaya dapat mengadakan pertimbangan yang sehat.

- Pemimpin berfungsi menggunakan kesempatan dan minat khusus anggota kelompok.

b) Fungsi yang bertalian dengan suasana pekerjaan yang sehat dan menyenangkan

- Pemimpin berfungsi memupuk dan memelihara kebersamaan di dalam kelompok.

- Pemimpin berfungsi mengusahakan suatu tempat bekerja yang menyenangkan, sehingga dapat dipupuk kegembiraan dan semangat bekerja dalam pelaksanaan tugas.

- Pemimpin dapat menanamkan dan memupuk perasaan para anggota bahwa mereka termasuk dalam kelompok dan merupakan bagian dari kelompok.

Kepemimpinan dalam penerapan manajemen sekolah memerlukan dua keterampilan yaitu keterampilan memimpin dan keterampilan mengelola 
(kepemimpinan dan manajerial). Perilaku kepemimpinan dalam melaksanakan keterampilan ini memegang peranan yang sangat penting untuk untuk meningkatkan kualitas sekolah. Perilaku kepemimpinan yang positif dan mendukung terhadap penerapan manajemen kepala sekolah akan lebih mencapai keberhasilan. Hasil penelitian Douglas \& Hakim (2001), menemukan bahwa sebagian besar pemimpin yang hanya memberikan pelayanan untuk peningkatan kualitas tanpa ada perilaku yang mendukung, mengurangi keberhasilan pelaksanaan hasil manajemen kepala sekolah.

Sommer dan Merritt (1994) dan Rad (2005) juga berpendapat tentang perlunya pemimpin memberikan perhatian terhadap strategi manajemen mutu terpadu karena secara signifikan perilaku hubungan kepemimpinan dengan perilaku karyawan memiliki pengaruh terhadap keberhasilan pelaksanaan manajemen mutu terpadu. Perbedaan perilaku kepemimpinan dan bawahan dalam merumuskan dan melaksanakan kebijakan manajememen mutu terpadu juga akan terlihat lebih nyata pada pelaksanaan manajemen mutu terpadu dan kinerja organisasi dalam sektor jasa seperti sekolah.

Sementara itu, Tiong (dalam Usman, 2011: 290) menemukan dalam penelitiannya tentang karakteristik perilaku kepala sekolah yang efektif antara lain sebagai berikut.

1. Kepala sekolah yang adil dan tegas dalam mengambil keputusan

2. Kepala sekolah yang membagi tugas secara adil kepada guru

3. Kepala sekolah yang menghargai partisipasi staf

4. Kepala sekolah yang memahami perasaan guru

5. Kepala sekolah yang memiliki visi dan berupaya melakukan perubahan

6. Kepala sekolah yang terampil dan tertib

7. Kepala sekolah yang berkemampuan dan efisien

8. Kepala sekolah yang memiliki dedikasi dan rajin

9. Kepala sekolah yang tulus

10. Kepala sekolah yang percaya diri

Sedangkan perilaku kepemimpinan yang tidak efektif antara lain mencerminkan semangat yang rendah, berpandangan sempit, diktator dan tidak memiliki rasa keterlibatan dalam organisasi.

Dengan kata lain perilaku kepala sekolah harus menyesuaikan dengan empat prinsip manajemen mutu terpadu. Penjelasan masing-masing prinsip dan perilaku kepemimpinan kepala sekolah dijelaskan di bawah ini.

1. Kepuasan Masyarakat

Seperti penjelasan sebelumnya, sekolah memiliki pelanggan internal dan eksternal. Terhadap pelanggan internal, siswa guru dan staf usaha perilaku kepala sekolah yang efektif antara lain adil dan tegas dalam mengambil keputusan, memiliki dedikasi dan rajin, memiliki keterampilan dalam pencegahan masalah, memiliki strategi mutu dan memiliki strategi evalusi yang 
jelas. Sedangkan terhadap pelanggan eksternal perilaku efektif kepala sekolah dapat tercermin melalui transparansi, pemberi informasi, melihat mutu sebagai sebuah cara untuk meningkatkan kepuasan pelanggan, dan menyikapi komplain sebagai peluang untuk belajar.

2. Respek terhadap setiap orang

Prinsip ini melihat setiap orang dalam sekolah sebagai aset dan memiliki potensi. Sehingga perilaku kepemimpinan yang efektif dalam mencerminkan prinsip ini adalah fasilitator, menghargai partisipasi staf, memahami perasaan guru, memberikan dukungan, melibatkan guru dan staf dalam pengambilan keputusan, mengembangkan dan membimbing potensi, memotivasi dan memberi inspirasi, mendelegasikan tugas, dan semua masyarakat sekolah dianggap memiliki peluang untuk menciptakan mutu.

3. Manajemen berdasarkan fakta

Pada prinsip ini, perilaku kepemimpinan kepala sekolah yang efektif tertib administrasi sehingga selalu mengambil keputusan dengan berdasarkan data organisasi yang jelas, bukan suatu gambaran atau perkiraan. Kepala sekolah juga merencanakan, mengorganisasi dan melakukan prioritas menggunakan data dan kondisi sumber daya dalam organisasi.

4. Perbaikan terus menerus

Dalam mencapai manajemen mutu, maka perubahan adalah hal yang mutlak dilakukan suatu organisasi seiring dengan perubahan perilaku pelanggan. Maka perilaku kepemimpinan kepala sekolah yang efektif mencerminkan pemantauan, visioner, transformasional, rencana jangka panjang, membangun jaringan kerja dengan pelanggan eksternal, inovatif, dan kreatif.

Ada konsep yang di populerkan oleh bapak Ki Hajar Dewantara tidak hanya dikenal sebagai bapak Pendidikan, namun juga sebagai pemimpin yang tangguh. Dimana ia memotivasi orang-orang untuk terus menerus belajar dan belajar tanpa henti. Kharismanya sebagai pemimpin dalam memajukan pendidikan menjadikan ajarannya terus menjadi motivasi hingga sekarang. (Sudirga, 2006: 25)

\section{Ing Ngarso Sun Tulodo}

Ing Ngarso mempunyai arti di depan/di muka, Sun berasal dari kata Ingsun yang artinya saya, Tulodo berarti tauladan. Jadi makna Ing Ngarso Sun Tulodo adalah menjadi seorang pemimpin harus mampu memberikan suri tauladan bagi orang - orang disekitarnya. Sehingga yang harus dipegang teguh oleh seseorang adalah kata suri tauladan. Jadi seorang kepala sekolah mampu menjadi tauladan bagi setiap warga sekolah.

Dalam ajaran Ki Hajar Dewantara yang pertama ini menggambarkan situasi dimana seorang pemimpin bukan hanya sebagai orang yang berjalan di depan, namun juga harus menjadi teladan bagi orang-orang yang mengikutinya. Kata Ing 
Ngarso tidak dapat berdiri sendiri, jika tidak mendapatkan kalimat penjelas dibelakangnya.

\section{Ing Madyo Mangun Karso}

Ing Madyo artinya di tengah-tengah, Mangun berarti membangkitan atau menggugah dan Karso diartikan sebagai bentuk kemauan atau niat. Jadi makna dari kata Ing Madyo Mangun Karso adalah seseorang ditengah kesibukannya harus juga mampu membangkitkan atau menggugah semangat. Karena itu seseorang juga harus mampu memberikan inovasi-inovasi dilingkungannya dengan menciptakan suasana yang lebih kodusif untuk keamanan dan kenyamanan. Selain itu pemimpin harus kreatif dalam memimpin, sehingga orang yang dipimpinnya mempunyai wawasan baru dalam bertindak. Ditambah lagi seorang pemimpin harus melindungi segenap orang yang dipimpinnya. Jadi seorang kepala sekolah mampu berada di tengah-tengah warga sekolah dalam memberikan nasihatnasihat yang dialami oleh warga sekolah.

\section{Tut Wuri Handayani}

Tut Wuri artinya mengikuti dari belakang dan Handayani berati memberikan dorongan moral atau dorongan semangat.

Ajaran kepemimpinan yang ketiga ini merupakan semboyan dari dunia Pendidikan, yang tentunya mempunyai makna yang mendalam. Jika diartikan secara keseluruhan Tut Wuri Handayani bertujuan untuk menciptakan pribadi yang Mandiri dan tidak bergantung kepada orang lain. Dan diharapkan akan muncul generasi baru yang akan berani memimpin tanpa menunggu orang lain untuk memimpin.

Adapun dorongan yang diberikan oleh seorang kepala sekolah tersebut dapat berupa moral dan semangat kepada orang lain. Maka dari itu pendidikan mengambil semboyan ini, agar pendidikan menjadi sebuah perantara membentuk generasi mandiri dan tidak bergantung pada orang lain. Maka dimasa yang akan datang dengan pendidikan yang dimilikinya orang tersebut tidak akan mudah untuk diperalat.

\section{KESIMPULAN}

Kepemimpinan kepala sekolah yaitu proses pemahaman seorang guru dalam memberikan arti mengenai kepemimpinan yang dijalankan oleh kepala sekolah berdasarkan pengamatan, pengalaman, perhatian dan kepercayaan yang terseleksi selama menjadi guru. Dapat disimpulkan bahwa dalam tubuh sekolah, kepemimpinan hendaknya dikembangkan diantara semua guru, di semua tingkatan. Semua guru hendaknya berpartisipasi dalam mengembangkan visi dan misi sekolah menghadapi era masa depan. Semua anggota kelompok organisasi hendaknya rela menerima tanggung jawab baru, mengambil resiko, membina konsensus, dan saling percaya mempercayai di antara kolega. Pemimpin harus 
yakin bahwa semua orang memiliki keterampilan memimpin yang ada di dalam diri masing-masing, dan keterampilan tersebut dapat dikembangkan. Kepemimpinan bukan sesuatu yang mistik, akan tetapi terdiri atas sejumlah keterampilan yang dapat dilatih dan dikembangkan, walaupun disadari bahwa ada faktor bakat alami tertentu yang melekat pada setiap orang. Pemimpin adalah seseorang yang mempunyai kemampuan untuk memengaruhi perilaku orang lain dalam kerjanya dengan menggunakan kekuasaan. Kekuasaan adalah kemampuan untuk mengarahkan dan memengaruhi bawahan sehubungan dengan tugas-tugas yang harus dilaksanakannya. Menurut Stoner, semakin banyak jumlah sumber kekuasaan yang tersedia bagi pemimpin, akan makin besar potensi kepemimpinan yang efektif (Fattah, 2004: 88).

\section{DAFTAR PUSTAKA}

Budianto, Nanang. Kepemimpinan Pendidikan dalam Total Quality Management, Jurnal Falasifa. Vol. 2 No. 1, 2011.

Camilia, Gladys and Margery. Educational Organization and Administration: Concepts, Practices and Issues. USA: Prentice Hall, Inc, 1974.

Cribbin, James J. Kepemimpinan: Mengefektifkan Strategi Organisasi. Jakarta: Pustaka Binaman Presindo, 1990.

Drake, Rodman L. Seri IImu dan Seni Manajemen Bisnis, Kepemimpinan. Terjemahan Susanto Budidharmo. Jakarta: PT. Gramedia, 1993.

Greech, Bill \& Alexander Sudiro. Manajemen Mutu Terpadu. Jakarta: Bina Rupa Aksara, 1996.

Hersey, Paul, Ken Blanchard. Manajemen Perilaku Organisasi: Pendayagunaan Sumber Manusia. Terjemahan Agus Dharma. Jakarta: Erlangga, 1995.

Hicks, Herbert G., G. Ray Gullet. Organisasi: Teori dan Tingkah Laku. Terjemahan G. Kartasapoetra dan A.G. Kartasapoetra. Jakarta: Bumi Aksara, 1996.

Komaruddin. Ensiklopedi Manajemen. Bandung: Alumni, 1993.

Lee, Chriss. "Beyond Team Work", Training: The Magazine of Human Resource, 1990.

Mulyadi. Kepemimpinan Kepala Sekolah Dalam Mengembangkan Budya Mutu. Malang: UIN Maliki Press, 2010.

Mulyasa. Manajemen Berbasis Sekolah. Bandung: Rosdakarya, 2002.

Nawawi, Hadari. Administrasi Pendidikan. Jakarta: Gunung Agung, 1996.

Rahman (at all). 2006. Peran Strategis Kapala Sekolah dalam Meningkatkan Mutu Pendidikan. Jatinangor: Alqaprint, 2006.

Reksohadiprodjo, Sukanto, T. Hani Handoko, Organisasi Perusahaan. Yogyakarta: BPPE., 1987. 
Robbins, Stephen P. Perilaku Organisasi. Terjemahan Hadyana Pujaatmaka. Jakarta: PT Prenhallindo, 1996.

Sadili Samsudin. Manajemen Sumber Daya Manusia. Bandung: CV Pustaka Setia, 2006.

Schermerhorn, John R., Jr, James G. Hunt, and Richard N Osborn. Management Organizational Behaviors. USA: Jonh Willey and Sons, Inc., 1985.

Siagian, Sondang P. Teori dan Praktek Pengambilan keputusan. Jakarta: PT. Gunung Agung, 1997.

Sommer, S.M. \& Merritt, D.E. The Impact of a TQM Intervention on Workplace Attitudes in a Health-care Organization, Journal of Organizational Change Management,7(2), 53 - 62, 1994.

Sudirga, dkk., Buku Pelajaran Agama Hindu. Denpasar: Widya Dharma. Denpasar, 2006.

Suit, Jusuf dan Almasdi. Aspek Sikap Mental dalam Sumber Daya Manusia. Jakarta: Ghalia Indonesia, 1996.

Sutisna. Administrasi Pendidikan: Dasar Teoritis dan Praktek. Bandung; Aksara, 1993.

T.J., Douglas \& Judge W.Q. Total Quality Management Implementation and Competitive Advantage: The Role of Structural Control and Exploration. Academy of Management Journal, 44(1), 158-169, 2001.

Wahjosumidjo. Kepemimpinan Kepala Sekolah. Jakarta: PT Raja Grafindo Persada, 2002.

William, M.R. Performance Appraisal in Management. London: Heineman, 1972.

Wirawan. Kapita Selekta Teori Kepemimpinan. Jakarta: Unamka Press, 2002.

Yukl, Gary. Leadership in Organization. Englewood Cliffs, New Jersey: Prentice Hall, 1944. 